\title{
"SE ELA É NÃO-BINÁRIA, POR QUE SE REFEREM NO FEMININO?": UM CORPO ESTRANHO EM DISPUTA ${ }^{1}$
}

\author{
"IF SHE IS NON-BINARY, WHY DO YOU REFER IN FEMININE?": A STRANGE \\ BODY IN DISPUTE
}

"SI ELLA ES NO BINARIA, POR QUÉ SE REFIEREN EN EL FEMENINO?": UN CUERPO EXTRAÑO EN DISPUTA

\author{
Ronaldo Cesar Henn² \\ Marlon Santa Maria Dias ${ }^{3}$
}

Resumo - $\mathrm{O}$ artigo analisa os sentidos sobre as concepções de gênero oriundos do caso envolvendo um crime contra uma pessoa não binária. O mapeamento é feito em 1512 comentários de leitores em duas publicações referentes ao caso no Facebook - uma do jornal o Globo e outra do programa televisivo Fantástico. Por meio da Análise de Construção de Sentidos em Redes Digitais, metodologia para o estudo de ciberacontecimentos, constatou-se a emergência de sete constelações de sentido: alteridade e reconhecimento; deboche; caráter pedagógico; enfoque no crime e deslegitimação do gênero; desqualificação do jornalismo; desejo de morte; e normalização. Orientados pela cristalização de construções histórico-culturais sobre o gênero, os sentidos identificados potencializam os processos de desumanização de corpos dissidentes à norma cisgênera e heterossexual.

Palavras-chave: Ciberacontecimento. Jornalismo. Gênero.

\footnotetext{
O presente trabalho foi realizado com apoio da Coordenação de Aperfeiçoamento de Pessoal de Nível Superior - Brasil (CAPES) - Código de Financiamento 001. Uma versão prévia deste texto foi apresentada no I Aquenda Seminário Nacional de Comunicação, Gêneros e Sexualidades, realizado em agosto de 2018, em Porto Alegre, RS. 2 Universidade do Vale do Rio dos Sinos, São Leopoldo, RS, Brasil. . ORCID: 0000-0002-3741-2936. E-MAIL: henn.ronaldo@gmail.com

3 Universidade do Vale do Rio dos Sinos, São Leopoldo, RS, Brasil. ORCID: 0000-0002-0175-9217. E-MAIL: marlon.smdias@gmail.com
} 


\begin{abstract}
The article analyzes the senses about gender conceptions arising from the case involving a crime against a non-binary person. The mapping has 1512 comments from readers in two journalistic vehicles publications on Facebook - one from O Globo newspaper and another from the TV show Fantástico. Through the Analysis of Sense Construction in Digital Networks, methodology for the study of cyberevents, it was verified the emergence of seven constellations of senses: alterity and recognition; mockery; pedagogical type; focus on crime and delegitimization of gender; disqualification of journalism; death wish; normalization. Guided by the crystallization of historical-cultural constructions on gender, the senses identified potentiate processes of dehumanization of dissident bodies to the cisgender-heterosexual norm.
\end{abstract}

Keywords: Cyberevent. Journalism. Gender.

Resumen - El artículo analiza los sentidos sobre concepciones de género provenientes del caso involucrando un crimen contra una persona no binaria. La cartografía se realiza en 1512 comentarios de lectores en dos publicaciones referentes al caso en Facebook, una del diario O Globo y otra del programa televisivo Fantástico. Por medio del Análisis de Construcción de Sentidos en Redes Digitales, metodología para el estudio de ciberacontecimientos, se constató la emergencia de siete constelaciones de sentido: alteridad y reconocimiento; burla; carácter pedagógico; enfoque en el crimen y deslegitimación del género; descalificación del periodismo; deseo de muerte; normalización. Orientados por la cristalización de construcciones histórico-culturales sobre género, los sentidos identificados potencian procesos de deshumanización de cuerpos disidentes a la norma cisgénera y heterosexual.

Palabras clave: Ciberacontecimiento. Periodismo. Género.

\title{
Introdução
}

"Através do meu corpo me comprometo a ir contra uma história de poucos leitores".

(MATHEUSA, 2019)

Matheusa Passareli Simões Vieira tinha 21 anos e era estudante de Artes Visuais na Universidade Estadual do Rio de Janeiro (UERJ). Em 2015, mudou-se de sua cidade natal, Rio Bonito (RJ), para viver e cursar o ensino superior no Rio de Janeiro. Morava com a sua irmã mais velha, Gabe Passareli, que dois anos antes havia se mudado para a capital fluminense. Registradas ao nascer como Matheus e Gabriel, ambas se identificavam como pessoas não binárias (ou "bichas travestis" ou "transexuais não binárias"). Em entrevista à BBC Brasil, Gabe explica as suas 
identidades de gênero: "É um lugar de intersecção entre ser homem e mulher. É uma questão mais de comportamento, de acabar com o 'ele' e 'ela', do que de mudança de sexo" (MESQUITA, [2018]).

Matheusa se mantinha com uma bolsa-auxílio de 500 reais que a UERJ oferece a estudantes cotistas. Para completar a renda, desde que chegara à cidade, trabalhava para museus e projetos de arte e moda. Ela também fazia tatuagens handpoked, usando apenas agulha e tinta, sem máquina. No dia 28 de abril de 2018 , ela saiu de uma reunião na agência de modelos em que trabalhava e se dirigiu até o bairro do Encantado, na Zona Norte do Rio de Janeiro. Lá haveria uma festa para a qual a jovem havia sido chamada para tatuar a aniversariante. Segundo o relato de testemunhas, ela não chegou a realizar as tatuagens, passou mal e foi embora ${ }^{4}$.

No dia seguinte, preocupados com o desaparecimento da estudante, família e amigos passaram a compartilhar nas redes digitais postagens com fotos de Matheusa, pedindo que as pessoas reportassem qualquer informação sobre o seu paradeiro. O desaparecimento começou a ser investigado pela Delegacia de Descoberta de Paradeiros e organizou-se uma mobilização online em torno do caso, orquestrada em torno da hashtag \#cadêMatheusaPassareli, inclusive, com a criação de uma página no Facebook, "Cadê Matheus Passareli - Theusa?".

No dia 7 de maio, uma semana após o sumiço, a polícia informou que, segundo as investigações, Matheusa foi parar no Morro do 18, favela em Água Santa, a dois quilômetros de onde ocorria a festa em que estava. Em entrevista à imprensa, a delegada Ellen Souto afirmou que a jovem estava nua quando um grupo de traficantes encontrou-a e resolveu submetê-la a um "julgamento informal". "Em meio à situação, Matheusa parecia alheia e seguia dizendo frases desconexas. De acordo com a polícia, a reação de Matheusa teria precipitado a execução por parte dos traficantes" (MESQUITA, [2018])5. Em postagem no Facebook, sua irmã escreveu: "Seu corpo [...] foi queimado e poucas são as possibilidades de encontrarmos alguma materialidade, além das milhares que a Matheusa deixou em vida e que muito servirão para que possamos ressignificar a realidade brutal que estamos vivendo" (PASSARELI, [2018]).

\footnotetext{
4 As informações sobre a vida de Matheusa inseridas neste texto foram retiradas de matérias jornalísticas publicadas sobre o caso em O Globo, Estadão, Folha de S. Paulo, Revista Fórum e BBC Brasil.

5 O inquérito policial, enviado à Justiça no final de 2018, concluiu que Matheusa foi morta com um tiro de fuzil e teve o corpo esquartejado e incinerado. Dois traficantes foram acusados pelo homicídio. Até o fechamento deste texto, um dos acusados havia sido morto em confronto com a polícia e o outro seguia foragido. O corpo da vítima não foi encontrado.
} 
Depois que a mobilização sobre o desparecimento se constituiu nas redes, alguns veículos jornalísticos o pautaram. Identificamos uma cobertura mais centrada no caso realizada pelo jornal O Globo, cuja redação se situa no Rio de Janeiro. Ao longo de quinze dias, o site do jornal publicou nove matérias sobre o caso. Considerando os fluxos desencadeados pela intensa disputa de sentidos do acontecimento nas redes, o programa televisivo Fantástico, da Rede Globo, fez uma matéria sobre o caso, com foco na identidade não binária de Matheusa.

A partir da constituição desse acontecimento em rede, o objetivo deste texto é investigar os sentidos acerca das concepções de gênero que emergem no discurso de leitores. De modo mais amplo, a identificação dos sentidos acionados nos faz refletir sobre a (des)humanização de um "corpo estranho", produzida em processos transnarrativos que envolvem tanto o jornalismo quanto os atores fora desse sistema (leitores). Para tanto, analisamos os comentários feitos em duas publicações referentes ao caso: uma postagem publicada na página do jornal O Globo e outra na página do Fantástico, ambas no Facebook. A justificativa para a escolha desse corpus repousa na possibilidade de ter contato com diferentes textualidades: os comentários dos leitores e as matérias jornalísticas - as de O Globo acompanham o desenrolar do caso, enquanto a matéria do Fantástico se ocupa em explicar, como sinaliza o próprio título da reportagem, "O que significa ser não binário?".

Como procedimento metodológico, descrevemos as matérias, a fim de elucidar os tópicos de construção das notícias. O foco da análise se dirige, porém, à outra instância de produção discursiva: o espaço dos comentários. Nosso objetivo, como já sinalizado, é compreender quais sentidos emergem desses comentários quando a vítima do crime noticiado tem identidade de gênero dissidente à matriz (cisgênera e) heterossexual compulsória (BUTLER, 2013). Essa matriz se refere ao

[...] modelo discursivo/epistemológico hegemônico da inteligibilidade do gênero, o qual presume que, para os corpos serem coerentes e fazerem sentido (masculino expressa macho, feminino expressa fêmea), é necessário haver um sexo estável, expresso por um gênero estável, que é definido oposicional e hierarquicamente por meio da prática compulsória da heterossexualidade (BUTLER, 2013, p. 216).

O que nos mobiliza é termos notado, em pesquisa exploratória sobre o caso, o fato de a identidade de gênero ter sido um catalisador da atenção não só do jornalismo, mas especialmente dos leitores, que organizam seus comentários sobretudo em torno de questões sobre gênero e sexualidade. Nesse sentido, 
estruturamos o artigo de modo a apresentar: 1) a interpretação que fazemos do caso enquanto um ciberacontecimento; 2) o conceito de gênero como categoria analítica para a leitura do material empírico; 3 ) a descrição das matérias jornalísticas e análise dos comentários; e 4) algumas considerações que articulam inferências sobre os sentidos acionados.

\section{A produção do acontecimento}

O caso descrito no início deste texto apresenta contornos do que entendemos como um ciberacontecimento, conceito que designa a especificidade de determinados acontecimentos jornalísticos produzidos no âmbito das redes digitais (HENN, 2013). Tal conceito é formulado a partir de revisões das teorias do acontecimento em si e do acontecimento jornalístico em particular, as quais encontram ponto de coesão na compreensão de que os acontecimentos irrompem como singularidade e cuja ruptura reorganiza quadros de sentido que visam explicá-lo. Dentre essas teorias, destacamos a formulação de Quéré (2005), para quem o acontecimento está situado no campo da experiência e da afetação.

Seguindo a perspectiva de Quéré, é possível afirmar que o caso envolvendo o desaparecimento e a morte de Matheusa inscreve um campo problemático denso, cuja emergência mobiliza os sujeitos afetados pelo acontecimento a dar sentido a esse, articulando potenciais disputas semióticas. A constituição do caso se dá, sobretudo, pela intensa mobilização dos atores sociais na internet, que desde o dia 29 de abril passam a propagar cartazes virtuais que tinham como objetivo informar sobre o desaparecimento da jovem e buscar pistas sobre o seu paradeiro.

A indexação proposta pela hashtag \#cadêMatheusaPassareli reúne produções discursivas de quem se sentiu afetado pelo acontecimento, criando-se redes de solidariedade e de consternação. O perfil de Gabe Passareli é também importante vetor de amparo informativo - do pedido de ajuda para as buscas até a confirmação da morte. O sofrimento da família sobre a incerteza do que aconteceu com Matheusa é tornado público com a postagem que a sua irmã faz no Facebook (Figura 1). 
Figura 1 - Postagem de Gabe Passareli no Facebook

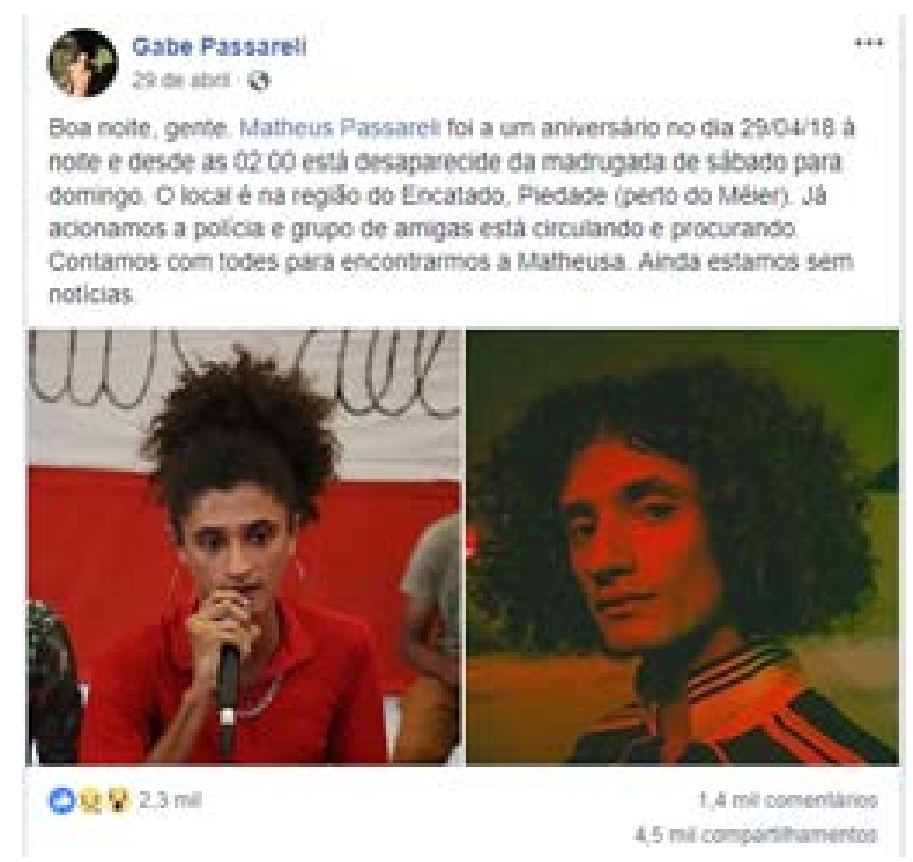

Fonte: GABE PASSARELI (2018).

A postagem atingiu 4.538 compartilhamentos e sinaliza para o que compreendemos como uma "nova modalidade no processo de acontecer" (HENN, 2013, p. 32). Sua constituição narrativa é tramada em rede e antecede a apreensão pelo jornalismo. No dia 30 de abril, apenas $O$ Globo publica notícia sobre o desaparecimento, com o título "Estudante da Uerj está desaparecido desde a madrugada de domingo" (AMIN; QUEIROGA, 2018). Só uma semana depois é que o caso passa a ter cobertura midiática mais estabelecida (não só por $O$ Globo, mas por outros veículos). Sua assimilação pelo sistema jornalístico ocorre devido ao desfecho trágico do caso, critério de noticiabilidade importante na eleição de temas a serem noticiados.

Ao observar um conjunto de notícias sobre o caso produzidas por diferentes veículos jornalísticos, percebemos que a identidade de gênero de Matheusa torna-se elemento central da narrativa. Em geral, as notícias buscavam explicar - ainda que superficialmente - o que é uma pessoa não binária. Era uma explicação necessária, inclusive para justificar a forma como os textos se referiam à vítima: com seu nome de registro, Matheus, masculino por convenção, mas flexionando pronomes e adjetivos no feminino. Identificamos nesse movimento uma tentativa, a partir de um caso singular, de o jornalismo propor novos mapas culturais de significado (HALL e outros, 1999) em relação a convenções de 
gênero ${ }^{6}$ já cristalizadas no discurso social. Posteriormente, esses sentidos são tensionados e confrontados no espaço das redes.

Para compreender como se dá a constituição do ciberacontecimento e analisar os dados, recorremos à Análise de Construção de Sentidos em Redes Digitais (ACSRD). Diferente de métodos que trabalham com escalas de sentido macro, como a Análise de Redes Sociais (FRAGOSO; RECUERO; AMARAL, 2011; RECUERO; BASTOS; ZAGO, 2015), a ACSRD desloca o foco para instâncias micro de constituição de conexões, "através das quais os atores sociais desencadeiam semioses específicas" (HENN; PILZ; MACHADO, 2018, p. 8). De inspiração cartográfica e ancorada no conceito peirceano de semiose, a metodologia opera-se nas seguintes etapas: 1) mapeamento e coleta (acompanhamento das conversações geradas a partir de um ciberacontecimento verificado); 2) identificação das nucleações de sentidos e categorização; e c) inferências dos sentidos oriundos das conversações do ciberacontecimento (HENN; PILZ; MACHADO, 2018). Via de regra, as inferências emergem com o auxílio do quadro conceitual oriundo do próprio campo problemático que o acontecimento desenha.

\section{Gênero, uma lente para a leitura do caso}

O fato de a cobertura sobre o crime pautar a identidade de gênero da vítima fez com que a questão mobilizadora deste trabalho fosse também orientada por uma perspectiva que encontra na categoria "gênero" uma lente de interpretação dos processos sociais, entre eles, os processos midiáticos. Especificamente, busca-se compreender os modos como as concepções de gênero estabelecem os jogos e disputas travadas pelos leitores nas conversações a partir das ofertas discursivas do jornalismo. Concordamos com Veiga da Silva (2014, p. 63), para quem "o jornalismo é um conhecimento social que se reproduz com uma função pedagógica cultural que pretende explicar os modos de ser e estar no mundo". É nesse sentido que compreendemos as notícias como uma forma de apresentação do mundo, atravessadas pelas visões dos jornalistas, que trazem implícitas os sistemas e hierarquias de valores hegemônicos na sociedade - tais como gênero, raça, etnia, classe etc. (VEIGA DA SILVA, 2014).

Nossa análise se localiza em uma perspectiva pós-estruturalista sobre o conceito de gênero, em seu caráter processual e relacional e como socialmente construí-

6 Convenções de gênero entendidas aqui como "o conjunto de valores e ideais relativos ao imaginário sexual disponíveis na cultura e compartilhados, a partir dos quais os seres sociais pautam as suas ações e concepções de mundo, reproduzem e recriam estas mesmas convenções e as suas práticas" (BONETTI, 2011). 
do. Nessa perspectiva, reflete-se sobre a naturalização do discurso biológico das diferenças sexuais, o que possibilita questionamentos referentes às convicções instituídas dentro de uma matriz social cisgênera e heterossexual vigente.

As demarcações de gênero podem ser compreendidas através das mais distintas operações sociais que dão significado tanto aos corpos sexualmente identificados quanto às relações sociais que os sujeitos estabelecem no interior da cultura na qual participam. Conforme Rosaldo (1995), o gênero deve ser compreendido nos termos políticos e sociais - enquanto arranjos institucionais - responsáveis por organizar e reproduzir os significados aos agrupamentos humanos. O gênero não faz referência apenas às determinações biológicas, cujo conjunto mínimo de disposições identificadas dificilmente suportariam conteúdos e efeitos particularmente diversos e variados, mas atenta "às formas locais e específicas de relações sociais e particularmente de desigualdade social” (ROSALDO, 1995, p. 22).

Nessa perspectiva, compreendemos a corporificação de Matheusa como vítima não apenas da violência contra a população LGBT+, mas também enquanto vítima da tradição conceitual [e midiática] que vê "essência" nas características atribuídas e presumidas pelas distinções tornadas naturais. As disputas de sentido atreladas ao caso, sobretudo os embates percebidos nas arenas discursivas entre os comentários dos leitores nas redes, demonstram o modo como o poder da referencialidade atribuída ao gênero organiza a inteligibilidade dos corpos através de processos de afirmação e de reafirmação das inúmeras instâncias pedagógicas (LOURO, 2003).

Meyer (2003) também compreende o conceito de gênero em função de pedagogias culturais pelas quais os indivíduos aprendem, ocupam e reconhecem os seus lugares nos espaços sociais, bem como os processos de distribuição de recursos sociais e simbólicos atribuídos de maneira diferenciante. Para a autora, o conceito de gênero está relacionado aos constructos socioculturais e linguísticos que são produto e efeito das relações de poder e que englobam todas as formas de construções sociais, culturais e linguísticas. Essas operações, mais do que produzirem corpos dotados de sexo, gênero e sexualidade, produzem e são produtoras de regimes de verdade que se traduzem nas formas de "hierarquias que são atribuídas aos sujeitos e que são, muitas vezes, assumidas pelos próprios sujeitos" (LOURO, 2003, p. 47).

A partir de distintos processos de delimitação, os sujeitos que não se enquadram às estruturas normativas, cujas identidades não são entendidas como humanamente possíveis, coerentes e desejadas, acabam por ser excluídos e 
marginalizados das mais variadas arquiteturas e arranjos sociais7 (BUTLER, 2013). Dessa forma, estruturam-se práticas que delegam posições de subalternidade aos sujeitos, tornando-os marginais e abjetos. Nos termos de Butler (2017), vidas que não são reconhecíveis como vidas e, portanto, não consideradas como potencialmente lamentáveis. Se os corpos possuem peso (BUTLER, 1993), ninguém quer ser aquele corpo por cujo pranto não há reivindicação: os corpos estranhos perturbadores das ordenações constituídas (HENN; MACHADO, 2016).

\section{Do texto jornalístico}

Em 30 de abril de 2018, o jornal O Globo publicou a primeira matéria sobre o desaparecimento de Matheusa. O caso permaneceu sendo pautado pelo jornal nos quinze dias seguintes, com um total de nove matérias publicadas (Quadro 1). É possível notar o seguinte movimento na cobertura: 1) noticiar o desaparecimento com a identificação do desaparecido (tratado no masculino), com informações da família, depois das testemunhas e um relato breve do que Matheusa teria feito antes de sumir; 2) noticiar a morte, confirmada pela irmã de Matheusa via redes sociais, caracterizando-a como execução e buscando aprofundar as informações não só pelo que continha o texto da irmã, mas entrevistando fontes oficiais ligadas à polícia; 3) destacar que o caso teve repercussão nas redes digitais, que envolveu não apenas os amigos de Matheusa, mas também celebridades, que se uniram em homenagem à jovem, com a produção de textos e imagens também publicadas em sites de rede social; 4) com a visibilidade do caso nas redes, há também uma exploração sobre a vida de Matheusa, com depoimento de familiares e amigos; 5) entra na narrativa referências ao trabalho artístico de Matheusa, que se ocupava da poética do "corpo estranho" (dissidente à norma), em um processo de escrita de si e ativismo LGBT+; 6) o caso volta a ser pauta quando fragmentos ósseos são encontrados, mas logo a perícia confirma que não são de Matheusa - com esse gancho, as reportagens recontam o caso.

\footnotetext{
7 A exclusão, entretanto, não necessariamente indica o aniquilamento/morte do outro, daqueles/as entendido/as como desviantes das normas de generificação. A exclusão indica processos ativos de produção da cultura, que produzem as subalternidades e os regimes sociais, simbólicos e materiais de inferiorização e de manutenção das hierarquias.
} 


\begin{tabular}{|c|c|c|}
\hline Data & Título & Chamada \\
\hline $30 / 04$ & $\begin{array}{l}\text { Estudante da Uerj está desaparecido desde a } \\
\text { madrugada de domingo }\end{array}$ & $\begin{array}{l}\text { Matheus Passareli saiu de uma festa e teria sido } \\
\text { visto pela última vez em Piedade }\end{array}$ \\
\hline $02 / 05$ & $\begin{array}{l}\text { Estudante da Uerj que está desaparecido foi } \\
\text { visto perto de comunidade no Rio }\end{array}$ & $\begin{array}{l}\text { Polícia Civil já ouviu testemunhas e vai analisar } \\
\text { câmeras de segurança da região }\end{array}$ \\
\hline $07 / 05$ & $\begin{array}{l}\text { Estudante da Uerj desaparecido há uma } \\
\text { semana foi executado, diz irmão }\end{array}$ & $\begin{array}{l}\text { Corpo de aluno de artes visuais teria sido } \\
\text { queimado; jovem foi visto pela última vez perto de } \\
\text { favela }\end{array}$ \\
\hline $07 / 05$ & $\begin{array}{l}\text { Amigos homenageiam estudante da Uerj } \\
\text { morta em comunidade do Rio }\end{array}$ & $\begin{array}{l}\text { Personalidades também postaram mensagens de } \\
\text { carinho e tributo a Matheus Passareli }\end{array}$ \\
\hline $07 / 05$ & $\begin{array}{l}\text { Irmã diz que Matheusa se 'doava muito às } \\
\text { pessoas e prezava a escuta' }\end{array}$ & $\begin{array}{l}\text { Corpo de estudante da Uerj ainda não foi } \\
\text { encontrado, mas delegada diz que ela foi vítima de } \\
\text { tribunal do tráfico }\end{array}$ \\
\hline $11 / 05$ & $\begin{array}{l}\text { Mãe e irmão prestam homenagem a Matheusa } \\
\text { em ato ecumênico na Uerj. }\end{array}$ & $\begin{array}{l}\text { Gabe leu trabalho da estudante que está } \\
\text { desaparecida e, segundo a polícia, foi morta }\end{array}$ \\
\hline $14 / 05$ & $\begin{array}{l}\text { Polícia encontra fragmentos de ossos em } \\
\text { comunidade onde Matheusa desapareceu }\end{array}$ & $\begin{array}{l}\text { Segundo investigação, estudante da Uerj teria sido } \\
\text { executada por traficantes do Morro do Dezoito }\end{array}$ \\
\hline $15 / 05$ & $\begin{array}{l}\text { Polícia encontra fragmentos óss[e]os em } \\
\text { comunidade onde Matheusa foi executada }\end{array}$ & $\begin{array}{l}\text { Agentes fizeram uma operação no Morro do } \\
\text { Dezoito como parte das investigações }\end{array}$ \\
\hline $15 / 05$ & $\begin{array}{l}\text { Ossos achados pela polícia em comunidade não } \\
\text { são de Matheusa }\end{array}$ & $\begin{array}{l}\text { Fragmentos encontrados onde estudante foi } \\
\text { morta eram de animal }\end{array}$ \\
\hline
\end{tabular}

Fonte: elaborado pelos autores (2019).

O mote de todas as matérias era o desaparecimento e a morte de Matheusa. Havia, porém, um aspecto que, com o passar dos dias, tornou-se central na narrativa do acontecimento: a identidade não binária da jovem. Se notarmos as matérias de $O$ Globo, as três primeiras se referem à Matheusa usando artigos, pronomes e adjetivos masculinos - ainda que desde a primeira notícia apareça a informação de que a jovem é não binária e que preferia ser identificada pelo feminino.

A partir da quarta reportagem, a não binaridade não é apenas informação auxiliar, mas elemento recorrente na cobertura e, de certa forma, interpretada como valor-notícia, já que a identidade de gênero é o que há de mais "incomum" no caso. Nesse sentido, os textos jornalísticos passam a explicar repetidamente o que é uma pessoa não binária. Interpretamos esse movimento como uma possível resposta do jornal a discursos sobre o caso que circulava nas redes digitais, onde reclamavam uma cobertura mais humanizada. Por conta disso, os textos 
de $O$ Globo, a partir da quarta matéria, passam também a se referir a Matheusa sempre no feminino.

No dia 13 de maio de 2018, o programa televisivo Fantástico, da Rede Globo, veiculou uma reportagem sobre o caso de Matheusa. Quando publicada no site, a reportagem foi intitulada como "Crime no Rio de Janeiro tem como alvo pessoa não binária (2018)"; no Facebook, a mesma reportagem traz o título "O que significa ser não-binário". Esse último título é mais coerente com o conteúdo da reportagem, cujo foco não é o desaparecimento ou a confirmação da morte da estudante, mas sim a não binaridade - a informação sobre o crime aparece só no final da matéria, inclusive.

A reportagem do Fantástico (2018) inicia-se com uma voz off narrando um texto sobre algumas das dualidades que constituem o mundo:

\begin{abstract}
Tem o dia, tem a noite. Tem o rápido, tem o lento. Tem o seco e tem o molhado. Tem o barulho, tem o silêncio. Tem o verão e tem o inverno. Mas nem tudo no mundo é uma coisa ou outra [na tela, aparece a palavra "primavera"]. Assim como nem todo mundo se considera homem ou mulher. São pessoas que não ficam limitadas a apenas duas possibilidades. Elas se definem como não binários.
\end{abstract}

Na sequência, a reportagem apresenta Triz, rapper que se identifica como pessoa não binária e será personagem central da narrativa. Na matéria, a sua experiência tem o valor de prova sobre o tema em discussão. Uma arte gráfica ilustra, com bonecos e símbolos do masculino e do feminino, o texto em que a repórter explica que existem cisgêneros e transgêneros, e que dentre estes há os binários e os não binários. A reportagem retoma a entrevista com Triz, que explica que a não binaridade também significa uma ruptura com as normatizações da linguagem - ao invés de usar "a" ou "o" para marcar o gênero nas palavras, opta-se pelo uso de "e", em geral. O programa ainda recorre à fala de um psiquiatra, cuja função é legitimar o que se relata a partir da posição autorizada e perita de um especialista. Por fim, a repórter relata o caso de Matheusa, com trechos de entrevistas com sua mãe e irmã.

Compreendemos que uma das funções que o jornalismo toma para si é a apresentação "do mundo como ele deve ser visto" (GOMES, 2004, p. 11). Nesse sentido, operando na construção social da realidade, o jornalismo traça mapas que orientam nossas formas de percepção, seus discursos "tornam-se expressões máximas do que é verdadeiro; e é com eles, vale dizer, que construímos os nossos modos de compreender e ver o mundo" (RESENDE, 2009, p. 5). Os sentidos ofertados pelo 
jornalismo sobre a multiplicidade de temas que compõem o mundo não estão distantes dos sentidos já cristalizados no tecido das discursividades sociais.

Ao observar as matérias produzidas sobre o caso de Matheusa, percebemos um esforço do jornalismo em pautar um tema invisível nas topografias jornalísticas hegemônicas e, por isso também, pouco conhecido/debatido pela sociedade. É notável que a discussão é motivada não apenas pelo crime em si, mas também pela intensa atividade dos atores sociais em rede, que reclamavam abordagens mais humanizadas em relação à cobertura do caso e destacavam a existência de Matheusa como uma pessoa não binária. São os próprios tensionamentos difusos advindos da instância de produção dos atores que conformam a narrativa jornalística e fazem com que as reportagens reiteradamente expliquem a identidade não binária e passem, em determinado momento, a se referir a ela no feminino.

Nesse sentido, o jornalismo propõe o que Hall e outros (1999) entendem como mapas culturais de significado sobre um tema pouco visibilizado. Se os mapas já consolidados se assentam sobre consensos, a proposição de novos mapas culturais se dá em um processo de embates. Como nos lembram Stocker e Dalmaso (2018, p. 258), as questões relacionadas a gênero "ainda se inserem no campo dos dissensos sociais, pois envolvem valores, crenças e hábitos naturalizados e construídos culturalmente". Se um mapa cultural consolidado opera pela norma, ele traz em si a potência de romper com essa norma, a partir da proposição de novos mapas. Essa condição de mutação é vital para a reprodução do que Butler (2017, p. 17) vai chamar de enquadramentos interpretativos - molduras que "não só organizam a experiência visual como também geram a criação de ontologias específicas do sujeito". Há sempre algo que o enquadramento não enquadra, algo que sobra - no extremo, sobram as vidas que não são reconhecidas como tal.

É a comoção gerada nas redes pela morte de Matheusa que tensiona a narrativa jornalística, rompe o enquadramento proposto e um novo mapa é gerado - no trabalho de apreensão da vida de Matheusa como uma vida reconhecível e passível de luto. No entanto, esse novo enquadramento proposto pelo jornalismo vai ser confrontado nas redes, no espaço dos comentários. Como vemos na sequência, observar essas zonas de contato entre os discursos sociais e os discursos midiáticos torna-se necessário e produtivo, pois o intento possibilita perceber (e refletir sobre) as formas como a naturalização sociocultural das identificações associadas ao gênero aparecem no texto jornalístico e no texto dos leitores. 


\section{Constelações de sentidos: a análise dos comentários}

Seguindo o objetivo proposto, observamos os comentários feitos por leitores em duas publicações - uma de O Globo e outra do Fantástico. A publicação do Fantástico escolhida foi a da matéria "O que é ser não-binário?" (FANTÁSTICO, 2018), com 957 comentários ${ }^{8}$. Como a página de $O$ Globo tinha nove publicações (referentes às matérias que constam no Quadro 1), utilizamos como critério a escolha da publicação de O Globo que tivesse mais comentários. Assim, selecionamos a postagem referente à matéria "Polícia encontra fragmentos de ossos em comunidade onde Matheusa desapareceu" (O GLOBO, 2018), que teve um total de 555 comentários".

A partir da análise desses textos, identificamos o que estamos nomeando de constelações de sentido, ou seja, agrupamentos semióticos que possibilitam a compreensão dos signos emergentes a partir de determinado acionamento. Formaramse sete constelações: alteridade e reconhecimento, deboche, caráter pedagógico, enfoque no crime e deslegitimação do gênero, desqualificação do jornalismo, desejo de morte, normalização (via religião, biologia, patologia ou linguagem). No Quadro 2, é possível visualizar a distribuição quantitativa das constelações, isto é, o número de comentários em cada publicação referente às sete nucleações. Em "Outros", incluímos os comentários não enquadrados em nenhuma constelação, por apresentarem frases pouco compreensíveis, marcação do perfil de outra pessoa (recurso recorrente para que essa pessoa também veja a publicação) e comentários aleatórios sobre outros temas sem referência direta à publicação.

\begin{tabular}{|l|l|l|l|}
\hline \multicolumn{1}{|c|}{$\begin{array}{l}\text { Ouadro 2 - Distribuicão quantitativa das constelacões } \\
\text { Constelações }\end{array}$} & \multicolumn{1}{|c|}{ ( Globo } & 74 & Total \\
\hline Alteridade/Recontico & 125 \\
\hline Deboche & 188 & 206 & 394 \\
\hline Caráter Pedagógico & 7 & 15 & 22 \\
\hline Enfoque no crime/deslegitimação do gênero & 84 & 65 & 149 \\
\hline Desqualificação do jornalismo & 67 & 94 & 161 \\
\hline Desejo de morte & 3 & 5 & 8 \\
\hline Normalização & 121 & 452 & 573 \\
\hline
\end{tabular}

\footnotetext{
8 Até o fechamento deste artigo.
}

9 Até o fechamento deste artigo. 


\begin{tabular}{|l|l|l|l|}
\hline Outros & 34 & 46 & 80 \\
\hline Total & 555 & 957 & 1512 \\
\hline
\end{tabular}

Fonte: elaborado pelos autores (2019).

Como já sinalizamos, a Análise de Construção de Sentidos em Redes Digitais é uma metodologia que visa a coleta de semioses em um plano micro. Priorizamse, portanto, os processos de semiotizações que ocorrem a partir das interações geradas nas conversações em rede. Ao identificarmos a emergência do ciberacontecimento, iniciamos o processo de mapeamento e coleta. A distribuição quantitativa das constelações indica pistas da propulsão semiótica do caso e aponta para a demarcação de territorialidades semióticas ${ }^{10}$. É importante sinalizar que, seja em escala macro ou micro, o que se pode apreender são sempre parcialidades de semioses - sendo essas sempre potencialmente ilimitadas.

Nomeamos a primeira constelação de alteridade e reconhecimento, visto que nela inscrevemos todos aqueles comentários que demonstram a possibilidade de reconhecer humanidade em Matheusa, expressando a dor causada pelo sofrimento e pela indignação frente à brutalidade do crime. A noção de alteridade é aqui entendida assentada na ideia de relação com a diferença, ou seja, o Outro, que é diferente e pode ser desconhecido, mas que não é lido como ameaça. Há, portanto, uma abertura ao encontro, como podemos ver nos comentários exemplares na Figura 2. Ainda que o conceito de identidade não binária fosse desconhecido pela maioria dos leitores, uma parcela deles se mostrou disposta a compreendê-lo e a não transformar a diferença em desigualdade.

10 Territorialidades semióticas designam espaços naquilo que luri Lotman (1996) chama de semiosfera, camada em que se metabolizam as semioses processadas na sociedade. Formam-se fronteiras que se tencionam entre a permeabilidade e o fechamento. 
Figura 2 - Constelação alteridade e reconhecimento

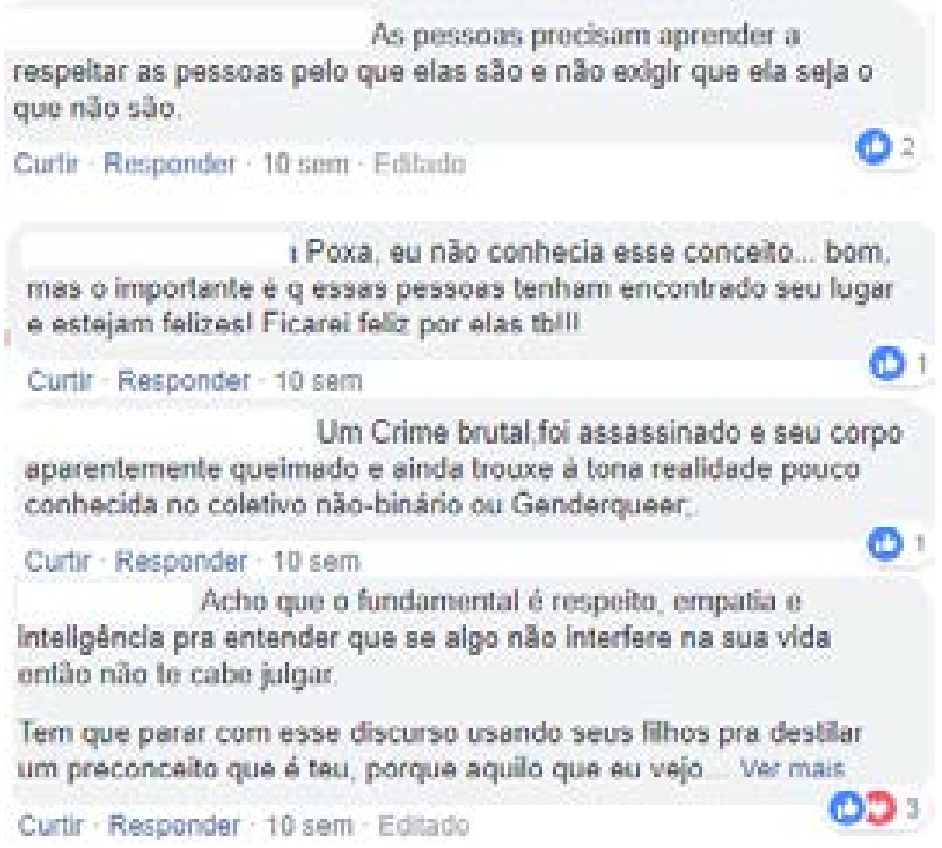

Fonte: Elaboração dos autores. Captura de tela a partir de FANTÁSTICO (2018) e O GLOBO (2018).

A constelação que agrega o segundo maior número de comentários é a do deboche. Nessa nucleação, inscrevemos os comentários que demonstram um fechamento a qualquer ideia que vá de encontro a crenças e noções naturalizadas e construídas culturalmente. Muitos dos comentários se utilizam de ironias para vilipendiar a vítima e todas as pessoas que se assemelham a ela (dissidentes da matriz cis-heteronormativa). Para tanto, utilizam-se especialmente de aspectos físicos para zombar e ridicularizar a vítima. Opera-se um processo de desumanização do "corpo estranho" (LOURO, 2006), que não é entendido como humanamente possível, e sua morte, portanto, não é lamentada (BUTLER, 2011, 2017).

Se nos comentários destacados na constelação anterior havia um movimento de abertura ao diferente - e, por conseguinte, da possibilidade de humanidade no corpo que foge à norma - os enunciados de deboche mostram o oposto. Em geral, fazem analogias com animais ou extraterrestes e desqualificam a aparência de Matheusa nas fotos que ilustram as matérias. Seus cabelos crespos e compridos e as roupas e acessórios que usa, convencionalmente femininos, são alvo de ridicularização. Um recurso recorrente é caracterizar a identidade não binária como uma "invenção" de movimentos de luta igualitária (como o LGBT+), de centros acadêmicos (universidades, especialmente as públicas) ou de setores situados no plano da esquerda do espectro político nacional. O conjunto de 
comentários dessa nucleação mostra que a discriminação do sujeito dissidente está articulada não apenas em função do gênero, mas também na intersecção com outros marcadores sociais, como raça, sexualidade, classe social, aparência física e geração (Figura 3).

Figura 3 - Constelação deboche

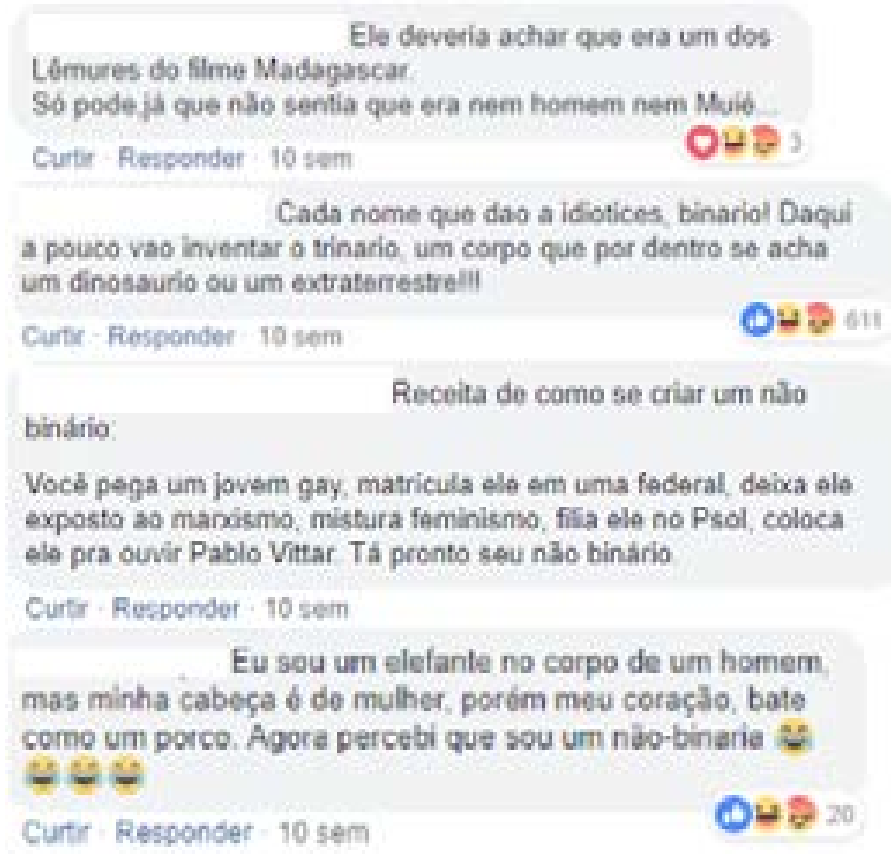

Fonte: elaboração dos autores. Captura de tela a partir de FANTÁSTICO (2018) e O GLOBO (2018).

Ainda que tenha uma quantidade menor em relação às outras nucleações, é qualitativamente importante destacar os comentários que possuíam um caráter pedagógico. Nessa constelação, reunimos os enunciados que visam explicar possibilidades de compreensão sobre a identidade não binária. Assim como os comentários de alteridade e reconhecimento, os de caráter pedagógico mostram uma abertura ao diferente. $O$ diferencial é que esses comentários trazem informações e explicações sobre o tema ou ainda fornecem links que direcionam para sites informativos acerca da temática. Esse movimento se mostra uma tentativa de combater os discursos de ódio e a construção de um espaço de debate no ambiente dos comentários (Figura 4). 
Figura 4 - Constelação caráter pedagógico

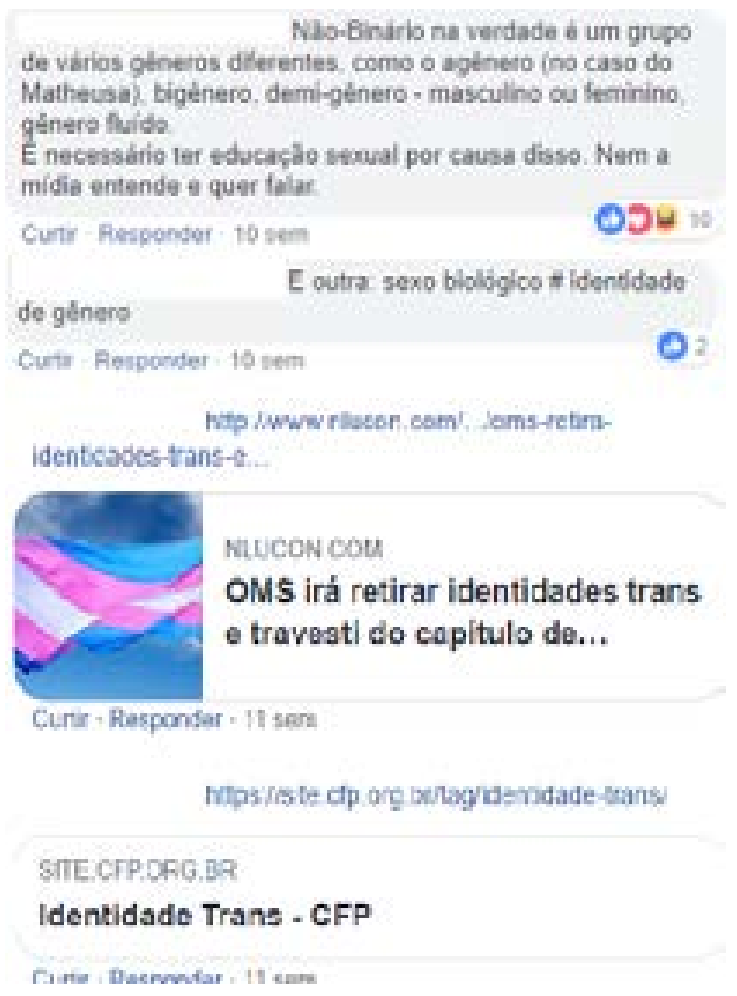

Fonte: elaboração dos autores. Captura de tela a partir de FANTÁSTICO (2018) e O GLOBO (2018).

Meyer (2003) trabalha o conceito de "pedagogias culturais" para se referir aos processos de aprendizagem e reconhecimento dos lugares sociais que ocorre em diferentes instâncias do social - não só na escola ou na família, mas também nos meios de comunicação social. Essa noção vai ao encontro do modo como Fischer (2002) entende a mídia: um dispositivo pedagógico. Certamente, as redes digitais são hoje também locus dessas pedagogias culturais. Os discursos que circulam nesses territórios atuam na tensão entre o reforço de concepções de gênero naturalizadas (como veremos nas próximas constelações) e resistências marcadas por movimentos educativos como os sinalizados nessa constelação.

Outra constelação de sentido que identificamos é a de enfoque no crime $e$ deslegitimação do gênero. Nela, agrupamos os comentários que afirmam que a discussão tergiversa o assunto mais importante: o crime cometido contra Matheusa (Figura 5). No entanto, quando os comentários reclamam uma abordagem focada no crime, há uma deslegitimação do gênero enquanto aspecto central na constituição da narrativa, considerando as questões de gênero apenas acessórias e culpabilizando a vítima a partir de uma perspectiva moralista. 
Figura 5 - Constelação enfoque no crime e deslegitimação do gênero

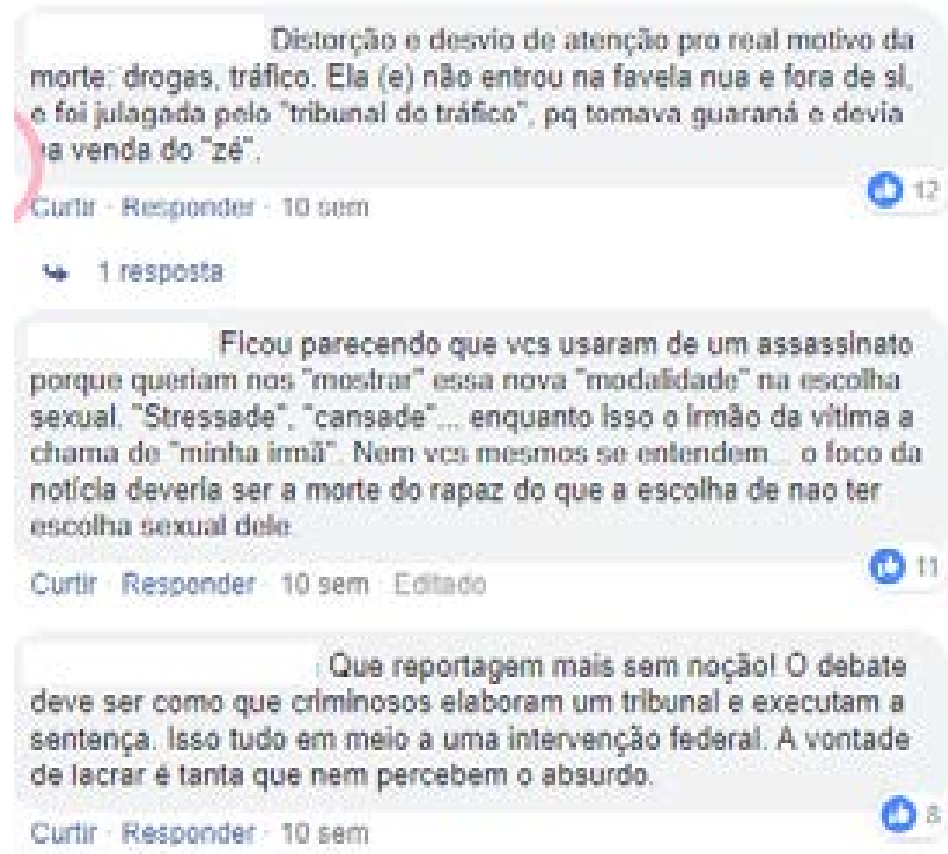

Fonte: elaboração dos autores. Captura de tela a partir de FANTÁSTICO (2018) e O GLOBO (2018).

Notamos um conjunto expressivo de comentários que reiteram um desinteresse pela identidade de gênero da vítima - segundo os enunciados, os assassinos também não estariam preocupados com a identidade de Matheusa e que tal informação não teria relevância para a elucidação do crime. Alguns comentários, como no exemplo destacado, apontam um oportunismo da mídia em tratar do caso simplesmente pelo fato de Matheusa ser não binária. Esses comentários, todavia, ainda tratam a vítima como um ser marginal ("louca", "drogada"): mesmo que a investigação policial não estivesse concluída, os leitores especulavam os motivos do crime e recorrentemente responsabilizavam a vítima pela própria morte.

Relacionada à constelação anterior, há ainda aquela que denominamos de desqualificação do jornalismo. Nela inscrevemos os comentários que entendem ser desnecessária e sem utilidade à reportagem (Figura 6). Para isso, recorrentemente os leitores fazem xingamentos direcionados ao jornal, ao programa, à emissora e aos repórteres, caracterizando como "lixo" o jornalismo produzido por eles. 
Figura 6 - Constelação desqualificação do jornalismo

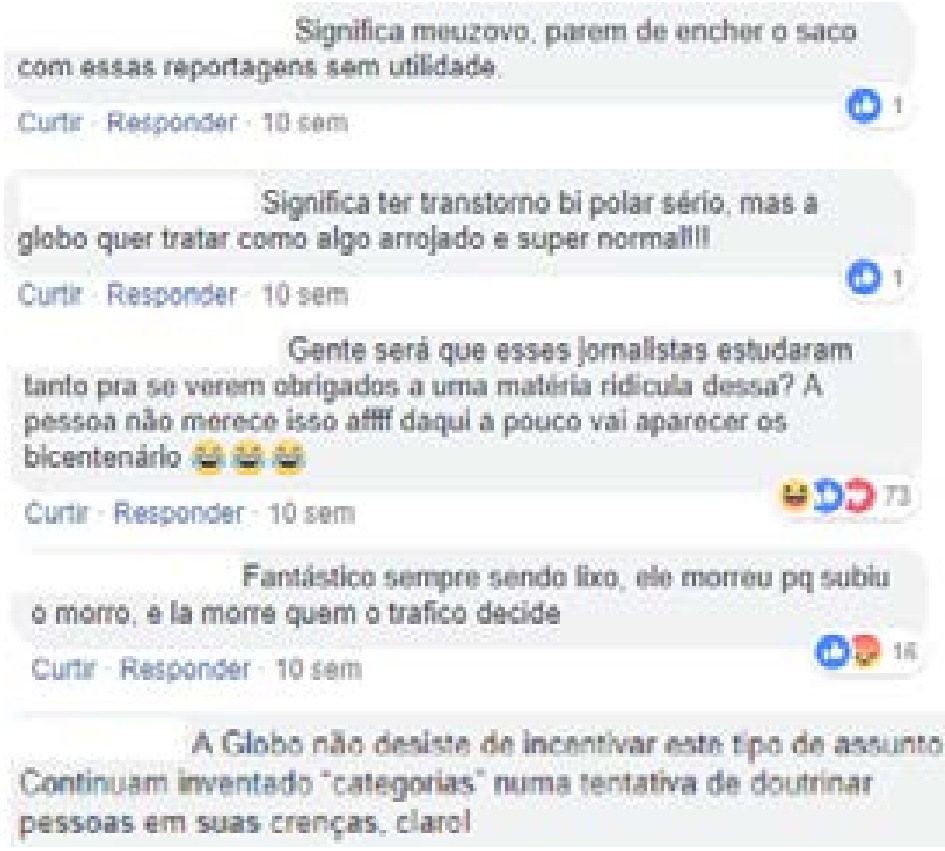

Fonte: elaboração dos autores. Captura de tela a partir de FANTÁSTICO (2018) e O GLOBO (2018).

Ao enunciado "O que significa ser não-binário?”, um dos leitores responde que "significa que o jornalismo morreu e não é de agora". Outros comentários mostram respostas ao mesmo enunciado, sinalizando a oposição dos leitores ao que Hall e outros (1997) chamaram de proposição de novos mapas de significado. Alguns leitores demonstram certo saudosismo do jornalismo produzido em décadas passadas, que não cobria temas sobre questões de gêneros e sexualidades. Há ainda um conjunto de comentários que responsabiliza a empresa (Globo) por "apologia a transtornos mentais" e pela "invenção de categorias", no caso a identidade não binária, entendida como parte de um projeto de doutrinação contrário a crenças consolidadas.

Há uma sexta constelação, referente aos comentários que verbalizavam o desejo de morte. Essa constelação é pouco expressiva, se considerada quantitativamente, mas a sua demarcação nessa análise é necessária, sobretudo se refletirmos os potenciais sentidos acionados. Assim como o deboche e a normalização (constelação que veremos na sequência), os comentários do conjunto desejo de morte estabelecem uma demarcação entre um Eu considerado normal (dentro da norma e padrão de referência) e um Outro (dissidente dessa matriz). Esse Outro é inumano, pois o reconhecimento de sua humanidade está atrelado à adequação do 
corpo às normas e à regulação de gênero. Como afirma Butler (2011), a condição de precariedade do Outro produz o desejo de morte, o desejo de matar.

Dos comentários selecionados, emergem sentidos que remetem à morte de Matheusa, expressando asco e cultivando o ódio - "é melhor morrer mesmo" (Figura 7). Os enunciados banalizam de forma material e simbólica não apenas a morte dessas populações (consideradas abjetas), mas também o fato de elas viverem uma vida que não atinge a potência de vida que pode ser vivida, ou seja, cuja morte não é passível de luto (BUTLER, 2017).

Figura 7 - Constelação desejo de morte

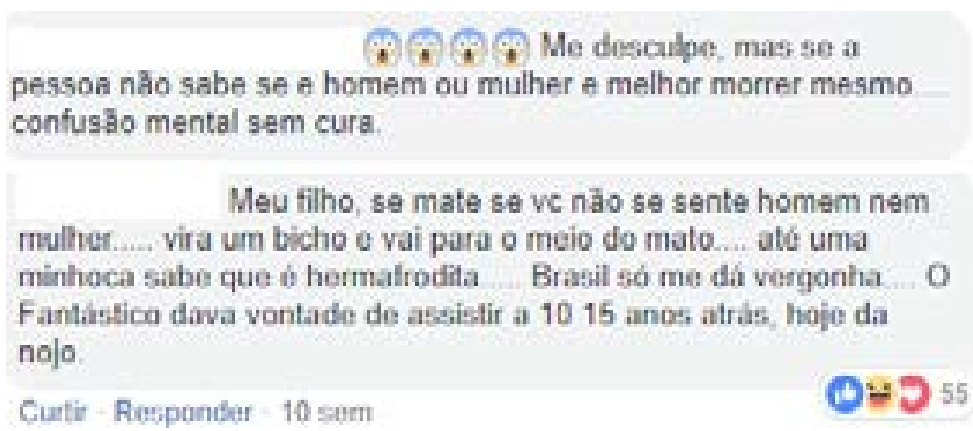

Fonte: elaboração dos autores. Captura de tela a partir de FANTÁSTICO (2018) e O GLOBO (2018).

Por fim, agrupamos em uma mesma constelação aqueles comentários que, por diferentes estratégias, buscam normalizar o "corpo estranho". Essa normalização opera via discurso religioso, biológico, patológico ou linguístico - essas estratégias não são excludentes, mas intercambiantes e coexistem nas materialidades semióticas. Consideramos que há processos sociais normalizadores que atuam na criação de classificações e hierarquizações - essas, por seu turno, "geram a ilusão de sujeitos estáveis, identidades sociais e comportamentos coerentes e regulares" (MISKOLCl, 2009, p. 169).

No conjunto da análise, a constelação de normalização foi a que mais agregou comentários (quase 40\% do total de comentários analisados). 54 comentários fazem referência a algum aspecto religioso para determinar que o corpo de Matheusa era anormal. Os comentários demonstram que havia pouco interesse sobre as informações apontadas pelas matérias sobre identidade de gênero, afinal, eram distintas do que consta na Bíblia. Esses enunciados reforçam que o ser humano foi criado por Deus, que a divisão se dá com base no sexo (homem/ macho $x$ mulher/fêmea) e que qualquer outro modo de interpretar (e viver) a existência dos corpos é pecaminoso (Figura 8). 
Figura 8 - Constelação normalização - religioso

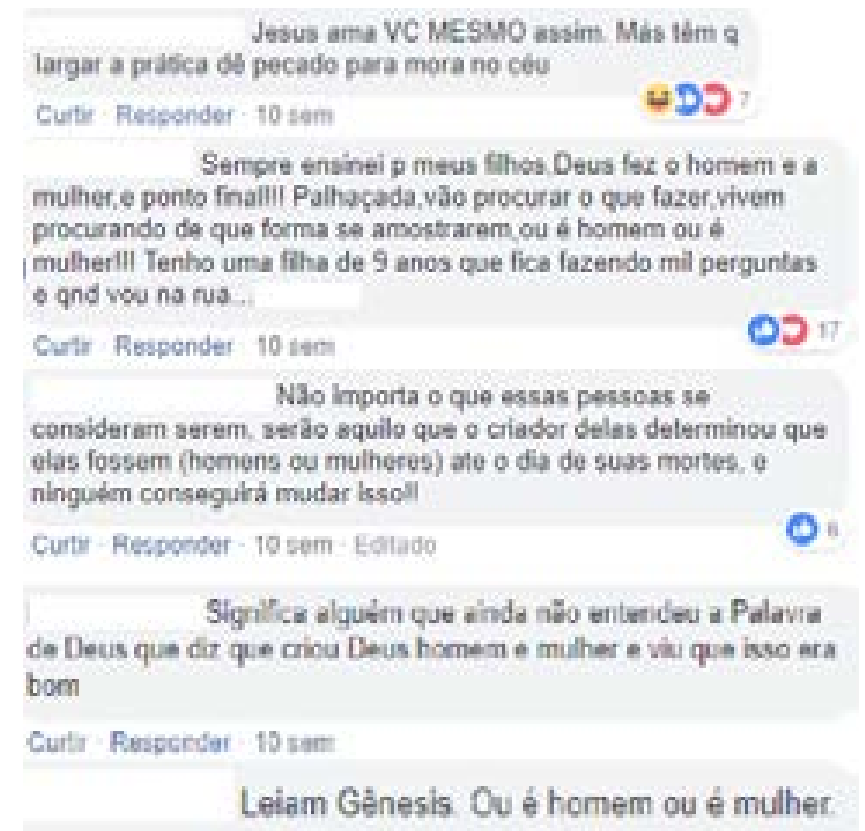

Fonte: Elaboração dos autores. Captura de tela a partir de FANTÁSTICO (2018) e O GLOBO (2018).

Em 147 comentários, a referência ao sexo biológico consta como matriz para o enquadramento de um corpo identificado como não binário (Figura 9). Como afirma Louro (2003, 2004), há uma naturalização do discurso biológico das diferenças sexuais que se assenta na correlação homem/pênis, mulher/vagina. Tudo que foge a essa norma é considerado "imaginário", "fantasioso", "ridículo", "ilógico". É também o aspecto biológico que organiza todos os demais elementos que culturalmente são relacionados a um e outro sexo - por exemplo, tipos de corte de cabelo, uso de acessórios, vestimentas e comportamentos adequados etc. 
Figura 9 - Constelação normalização - biológico

Só inventando colsa, esse powo já ultrapassou todas as fronteiras da lógica, agora vào para as fronteiras do imaginário, do ridiculo, do ilógico, contanto que dividam mais e mais - mundol Jả deu nél Jả surteul Já é demaisi Saudade do mundo que eu nasci onde existiam apenas homem e mulher $*$

Curtir - Responder - 10 sem - Editado

A realidade só é uma, essas pessoas nasceram com órgàos que determinam seu gênero . pénis ou vagina _e ponto. agora se resolveram mudar isso na cabeça deles ou delas problemas deles em geral, eu nāo sou obrigada a concordar com eles. Da licença né. Querem mudar sua natureza, como vieram ao mundo. E multa prepotência do ser humano

Curtir : Ressonder - 10 sem

Daqui a pouco surge o Nào

Humano e ele vaí bater o pé que näo é, e teremos que aceàtar porquê se nào seremos Nâo-humanofobicos !

Curtir Responder - 10 sem- Editado

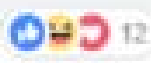

Fonte: Elaboração dos autores. Captura de tela a partir de FANTÁSTICO (2018) e O GLOBO (2018).

Figura 10 - Constelação normalização - patológico

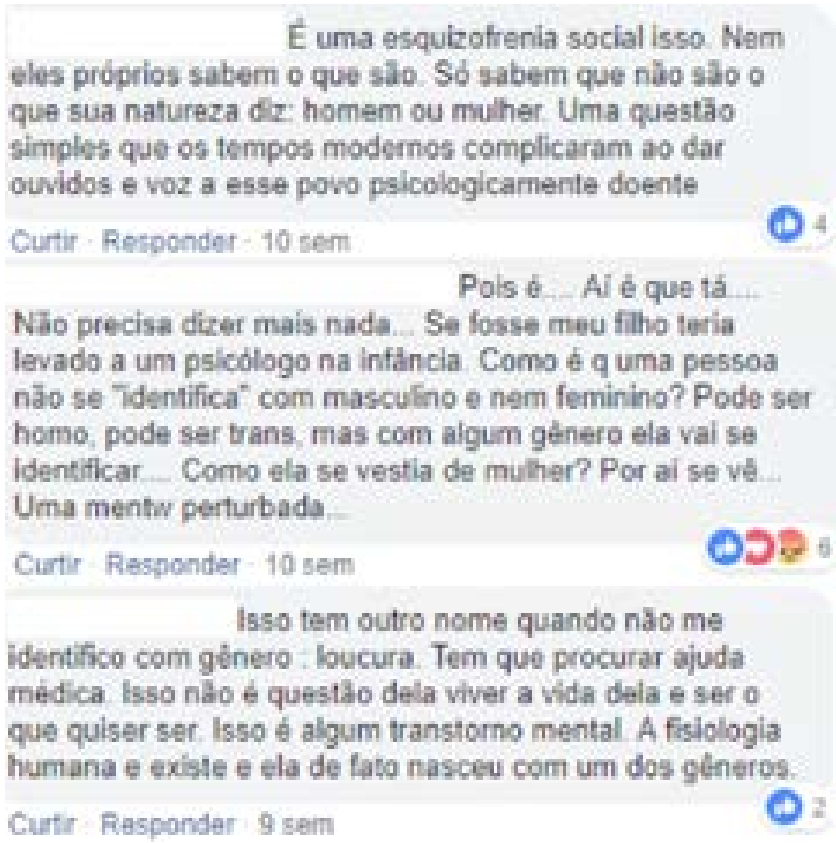

Fonte: Elaboração dos autores. Captura de tela a partir de FANTÁSTICO (2018) e O GLOBO (2018).

Ainda no intuito normalizador, a maioria dos comentários (150) dessa constelação interpretam a não binaridade por um viés patológico, caracterizando como "loucura" ou "transtorno" (Figura 10). Vê-se que há uma relação, nesses comentários, com o discurso biológico: se existem apenas dois sexos, duas possibilidades, qualquer desidentificação ou distorção à norma é lida como do- 
ença que necessita de urgente tratamento. Há, em todas essas estratégias de normalização, um completo fechamento à alteridade e, em algumas publicações, uma convocação à necessidade de silenciar o "povo psicologicamente doente".

Com 121 comentários, a última estratégia de normalização identificada na constelação também parte de um discurso biológico para caracterizar as diferenças sexuais, mas o argumento central repousa na referência linguística para classificar os gêneros. Segundo esses comentários, na língua portuguesa há apenas dois gêneros (feminino e masculino) e, portanto, essa seria a baliza para categorizar e excluir. Selecionamos alguns comentários que são exemplares dos sentidos acionados. O primeiro comentário reescreve, a seu modo, a informação que consta na matéria e sinaliza, em letra maiúscula, o " $O$ " no final dos adjetivos e o nome da vítima (Matheus), a fim de enquadrar o "corpo estranho" na norma (Figura 11).

Figura 11 - Constelação normalização - linguagem

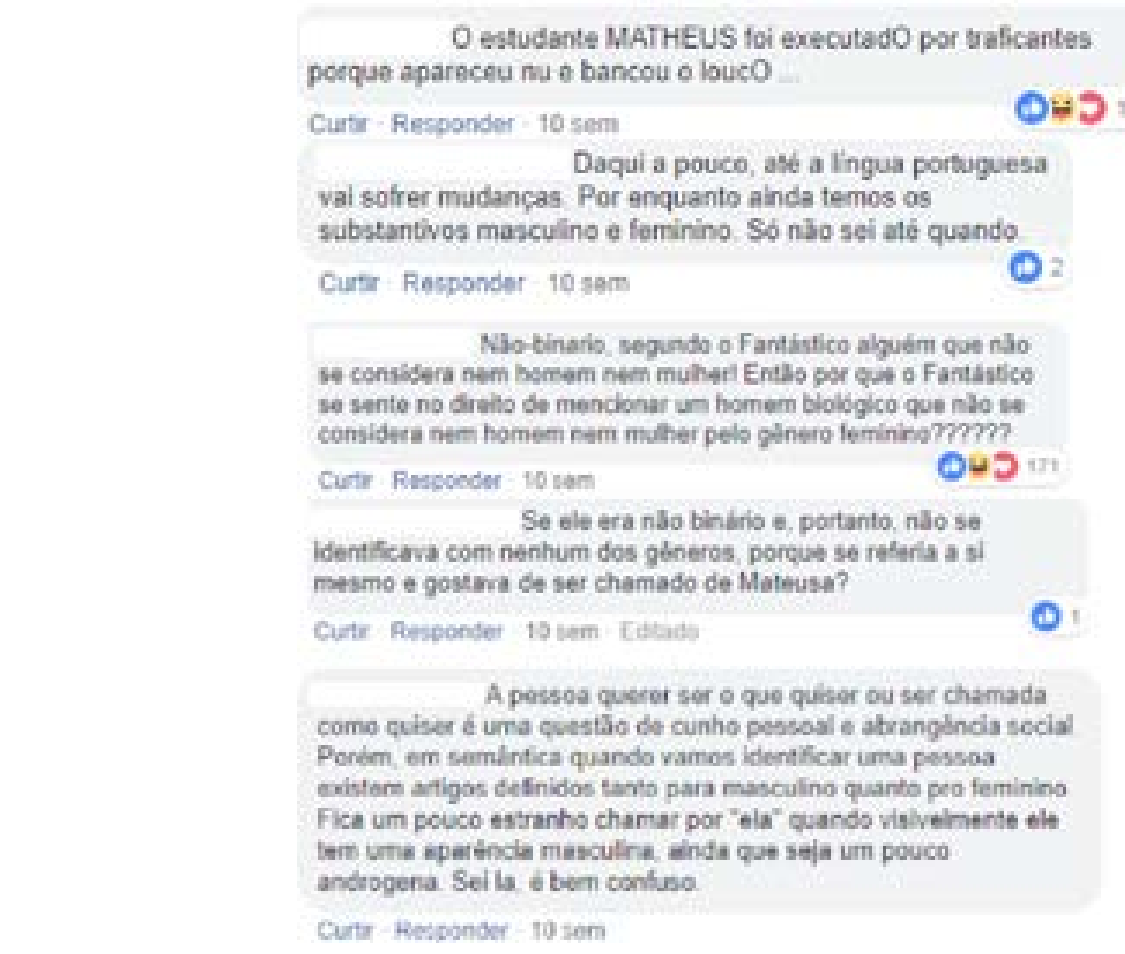

Fonte: Elaboração dos autores. Captura de tela a partir de FANTÁSTICO (2018) e O GLOBO (2018).

Alguns exemplos apontam para uma questão recorrente nos comentários: se Matheusa era uma pessoa não binária, por que o jornalismo a tratava no feminino? Esse questionamento é central para pensarmos o modo como a linguagem opera no processo de diferenciação dos corpos e, em consequência, o problema 
posto pelos corpos que fogem à norma e buscam romper e subverter as normatizações da língua. Butler (2013) entende a linguagem como um dispositivo a partir do qual os sujeitos são generificados. Nesse sentido, a linguagem atua no processo de distinção entre o que é feminino e masculino e na valoração entre os atributos - aqueles relacionados ao feminino acabam por ser valorados como inferiores aos considerados masculinos (BONETTI, 2011; VEIGA DA SILVA, 2014).

Não à toa, a aparição pública de Matheusa causa estranhamento e, como vimos, enorme rejeição. Um corpo que transita entre o masculino e o feminino e que renega o enquadramento em um dos polos. O jornalismo busca explicar: é uma pessoa não binária. A necessidade compulsória por classificar os corpos, no entanto, impele os leitores a questionarem por que, então, a chamam no feminino. A resposta mais direta está nas matérias: sem o apego à norma, ela tinha uma preferência pelo feminino. Qualquer resposta sobre o porquê dessa preferência seria especulativa, afinal, não podemos perguntar a ela. No entanto, é possível relacionar aos contextos de sociabilidade LGBT+ contemporâneos, no qual a referência ao feminino é comum, sobretudo entre gays afeminadas, bichas e travestis. Essa referência é atravessada pela jocosidade, em tom amistoso e íntimo, que articula a subversão dos usos generificados da língua. Essa subversão (e indefinição) desestabiliza os referenciais dos leitores que, mesmo involuntariamente, buscam enquadrar o corpo dentro das matrizes que orientam nossos modos de classificação.

\section{Considerações finais}

Matheusa finaliza o seu relato artístico, "Cartografia Social do Crescimento e Desenvolvimento", com a seguinte afirmação: "A convivência com o descaso se tornou naturalizada, assim como a morte de alguns corpos. Eu sinto muito". A frase prediz o que se materializa no conjunto de comentários analisados: há enquadramentos de poder que organizam a vida social e, ao estabelecerem matrizes normativas, elegem corpos e subjetividades que se tornam alvos preferenciais da violência insidiosa. Esses enquadramentos distribuem os corpos abjetos em uma hierarquia que lhes retira a possibilidade de reconhecimento como humanos.

Buscamos, neste texto, identificar e interpretar os sentidos acionados acerca das concepções de gênero nos comentários de matérias jornalísticas no Facebook. O objetivo posto foi impulsionado pela percepção de que a identidade não binária da vítima passou, em determinado momento, a organizar a produção discursiva sobre o caso. A exposição do corpo estranho na cena pública foi propulsora do 
acontecimento - o corpo, por si, já prenhe de potência acontecimental. Ao olharmos as notícias, percebemos que a narrativa se constituía por processos transnarrativos, incorporando a reverberação e a presença dos atores em rede. A demanda por uma cobertura "mais humanizada" interferiu na narrativa jornalística, os enquadramentos são tensionados e linhas de fuga se desenham e desestabilizam a norma.

Direcionamos o nosso olhar para os comentários e constatamos a emergência de sete constelações de sentido. Apenas duas (alteridade e reconhecimento; caráter pedagógico) agrupavam sentidos que mostravam uma abertura ao diferente. As demais constelações indicam distintas estratégias de desumanização de um corpo dissidente à cis-heteronormatividade. Butler (2017) afirma que todas as vidas são precárias e que é a visibilidade dessa precariedade na esfera pública que encaminha a apreensão e o reconhecimento das vidas como vidas que contam ou não. Essa linha divisória é dada pela proibição do luto público para certas vidas. $\mathrm{O}$ que percebemos foi a potencialização de tensões semiosféricas na busca por hegemonia de sentidos: de um lado, um processo de humanização que opera pela expansão da esfera pública ao promover a visibilidade da vulnerabilidade; de outro, a violência dos processos de exclusão e reificação do Outro em identidades fixas.

Contudo, compreendemos que as atribuições ligadas ao gênero conduzem às formas de leitura e apreensão de realidades sociais e aos diferentes atributos que são relacionados a determinados corpos em contextos sociais específicos. Esses sistemas funcionam a partir de um ideal regulatório, processo contínuo de classificação e hierarquização, que produz a norma e a sua diferença. Essa separação materializa vivências e realidades sociais que são reguladas por diferenciais compartilhados. Ao mesmo tempo que figuras de exclusão são forjadas na vida social, emerge também uma multiplicidade de outros corpos, subjetividades e saberes que alargam as possibilidades de leitura do mundo.

\section{Referências}

AMIN, Julia; QUEIROGA, Louise. Estudante da Uerj está desaparecido desde a madrugada de domingo. $O$ Globo, 30 abr. 2018. Disponível em: https://glo.bo/2FKX 7 PV. Acesso em: 15 mar. 2019.

BONETTI, Alinne de Lima. Gênero, poder e feminismos: as arapiracas pernambucanas e os sentidos de gênero da política feminista. Labrys, v. 20, p. 41-51, 2011. Disponível em: https://bit.ly/2l3uRJC. Acesso em: 15 maio 2018. https://doi.org/10.21669/tomo. voin2.461 
BUTLER, Judith. Bodies that matter: on the discursive limits of sex. New York: Routledge, 1993.

BUTLER, Judith. Vida precária. Contemporânea, São Carlos, n.1, p. 13-33, jan.-jun. 2011.

BUTLER, Judith. Problemas de Gênero: feminismo e subversão da identidade. Rio de Janeiro: Civilização Brasileira, 2013.

BUTLER, Judith. Quadros de guerra: quando a vida é passível de luto? Rio de Janeiro: Civilização Brasileira, 2017.

CRIME NO RIO DE JANEIRO tem como alvo pessoa não binária. Fantástico, 13 maio 2018. Disponível em: https://glo.bo/2CNKyRK. Acesso em: 10 jul. 2018.

FANTÁSTICO. O que é ser não-binário? Rio de Janeiro, 13 maio 2018. Facebook: Fantastico. Disponível em: https://www.facebook.com/Fantastico/posts/1678237698880670. Acesso em: 10 jun. 2018. https://doi.org/10.5565/rev/brumal.538

FISCHER, Rosa Maria Bueno. O dispositivo pedagógico da mídia: modos de se educar na (e pela) TV. Educação e Pesquisa, São Paulo, v. 28, n. 1, p. 151-162, 2002. https://doi. org/10.1590/s1517-97022002000100011

FRAGOSO, Suely; RECUERO, Raquel; AMARAL, Adriana. Métodos de pesquisa para internet. Porto Alegre: Sulina, 2011.

GABE PASSARELI. Perfil pessoal. 29 de abril de 2018. Facebook: gabepassareli. Disponível em: https://www.facebook.com/gabepassareli/posts/10216318681669119. Acesso em: 15 maio 2018.

GOMES, Mayra Rodrigues. Jornalismo e filosofia da comunicação. São Paulo: Escrituras Editora, 2004.

HALL, Stuart e outros. A produção social das notícias: o "mugging" nos media. In: TRAQUINA, Nelson (org.). Jornalismo: questões, teorias e estórias. 2. ed. Lisboa: Vega, 1999, p. 224-248.

HENN, Ronaldo. O ciberacontecimento. In: VOGEL, Daisy; MEDITSCH, Eduardo; SILVA, Gislene (org.). Jornalismo e acontecimento: tramas conceituais. Florianópolis: Insular, 2013 , v. 4, p. 31-48.

HENN, Ronaldo; MACHADO, Felipe V. O corpo como acontecimento semiótico: construções do self, performances e outras semiosis. Intexto, Porto Alegre, n. 37, p. 215-226, 2016. https://doi.org/10.19132/1807-8583201637.215-226

HENN, RonaldoPILZ, Jonas; MACHADO, Felipe V. K. Celebração do casamento igualitário e homofobia nas redes digitais: \#LoveWins na disputa de sentidos oriundos da apropriação da Havaianas. E-compós, v. 21, n. 1, p. 1-20, jan.-abr. 2018. https://doi. org/10.30962/ec.v21i1.1400 
LOTMAN, luri. La semiosfera. Madri: Catedra, 1996.

LOURO, Guacira Lopes. Currículo, gênero e sexualidade. O "normal", o "diferente e o "excêntrico". In: LOURO, Guacira; NECKEL, Jane Felipe; GOELLNER, Silvana V. (org.). Corpo, gênero e sexualidade: um debate contemporâneo na educação. Petrópolis: Vozes, 2003. p. 41-51. https://doi.org/10.9771/2317-1219rf.v12i11.2771

LOURO, Guacira Lopes. Um corpo estranho: ensaios sobre sexualidade e teoria queer. Belo Horizonte: Autêntica, 2004.

MATHEUSA. Cartografia Social do Crescimento e Desenvolvimento. Disponível em: https://bit.ly/2WyzLON. Acesso em: 20 mar. 2019

MESQUITA, Lígia. 'A gente não pode naturalizar o sofrimento', diz irmã de Matheusa Passareli, trans morta no Rio. BBC Brasil, Rio de Janeiro, 9 maio 2018. Disponível em: https://www.bbc.com/portuguese/brasil-44028880. Acesso em: 15 maio 2018.

MEYER, Dagmar Estermann. Gênero e educação: teoria e política. In: LOURO, Guacira; NECKEL, Jane Felipe; GOELLNER, Silvana V. (org.). Corpo, gênero e sexualidade: um debate contemporâneo na educação. Petrópolis: Vozes, 2003. p. 9-27.

MISKOLCI, Richard. A Teoria Queer e a Sociologia: o desafio de uma analítica da normalização. Sociologias, Porto Alegre, ano 11, n. 21, p. 150-182, jan.-jun. 2009. https:// doi.org/10.1590/s1517-45222009000100008

O GLOBO. Polícia encontra fragmentos de ossos em comunidade onde Matheusa desapareceu. Rio de Janeiro, 15 maio 2018. Facebook: jornaloglobo. Disponível em: https:// www.facebook.com/jornaloglobo/posts/2102429089796759. Acesso em: 10 jun. 2018.

PASSARELI, Gabe. Facebook, 2018. Disponível em: https://www.facebook.com/ GabrielPassareli/posts/10216374013532381. Acesso em: 15 maio 2018.

QUÉRÉ, Louis. Entre facto e sentido: a dualidade do acontecimento. Trajectos. Revista de Comunicação, Cultura e Educação, Lisboa, n. 6, p. 59-75, 2005.

RECUERO, Raquel; BASTOS, Marco; ZAGO, Gabriela. Análise de redes para mídia social. Porto Alegre: Sulina, 2015.

RESENDE, Fernando. A narratividade do discurso jornalístico - A questão do outro. Rumores, São Paulo, n. 6, p. 1-12, set.-dez. 2009. https://doi.org/10.11606/issn.1982-677x. rum.2009.51173

ROSALDO, Michelle. O uso e o abuso da antropologia: reflexões sobre o feminismo e o entendimento intercultural. Horizontes antropológicos, Porto Alegre, ano 1, n. 1, p. 10-36, 1995. 
STOCKER, Pamela; DALMASO, Silvana. A cultura do estupro entra na pauta: a disputa de sentido entre jornalismo e leitores do Diário Gaúcho. Brazilian Journalism Research, v. 14, n. 1, p. 256-281, 2018.

VEIGA DA SILVA, Marcia. Masculino, o gênero do jornalismo: modos de produção das notícias. Florianópolis: Insular, 2014. https://doi.org/10.22409/rg.v18i1.1047

\section{Dados dos autores}

Ronaldo Cesar Henn - henn.ronaldo@gmail.com

Doutor em Comunicação e Semiótica pela PUCSP. Professor/pesquisador do PPGCCOM da Unisinos, coordenador do LIC - Laboratório de Investigação do Ciberacontecimento e Pesquisador do CNPq, nível 2.

\section{Marlon Santa Maria Dias - marlon.smdias@gmail.com}

Doutorando em Ciências da Comunicação na Unisinos. Bolsista CAPES/PROEX. Jornalista e mestre em Comunicação pela UFSM. Integrante do LIC - Laboratório de Investigação do Ciberacontecimento.

\section{ENDEREÇO DOS AUTORES}

\section{Ronaldo Cesar Henn}

Programa de Pós-Graduação Em Ciências da Comunicação. Universidade do Vale do Rio dos Sinos (UNISINOS). Avenida Unisinos, 950, Cristo Rei, São Leopoldo, Rio Grande do Sul, Brasil 93022-000

\section{Marlon Santa Maria Dias}

Programa de Pós-Graduação Em Ciências da Comunicação. Universidade do Vale do Rio dos Sinos (UNISINOS). Avenida Unisinos, 950, Cristo Rei, São Leopoldo, Rio Grande do Sul, Brasil 93022-000 